\title{
Sustainable Tourism: A Hope or a Necessity? The Case of Tofino, British Columbia, Canada
}

\author{
Rachel Dodds ${ }^{1}$ \\ ${ }^{1}$ Ted Rogers School of Hospitality and Tourism Management, Ryerson University, Canada \\ Correspondence: Rachel Dodds, Ted Rogers School of Hospitality and Tourism Management, Ryerson University, \\ 350 Victoria Street, Toronto, Ontario, M6G 3H1, Canada. Tel: 1-416-979-5000 x7227. Email: \\ r2dodds@ryerson.ca
}

Received: February 17, 2012 Accepted: April 18, 2012 Online Published: May 1, 2012

doi:10.5539/jsd.v5n5p54

URL: http://dx.doi.org/10.5539/jsd.v5n5p54

\begin{abstract}
With many communities now dependent on tourism for their economic livelihood, long-term sustainability through a local, multi-stakeholder process is becoming key for destination management. Tofino, which was originally a remote, fishing village, has repositioned itself as an international tourism destination. Home to approximately 1,655 full-time residents, the town now attracts over 750,000 tourists per year. With the contentious Clayoquot Sound Land Use Decision in 1995 that aimed to disrupt the logging industry, this saw the beginning of a major increase in tourism demand in the area. Businesses developed focusing on adventure and ecotourism and restaurants, coffee shops, retail opportunities and accommodations are now plentiful. Although tourism has brought many benefits, challenges such as infrastructure, resource management, cost of living and social issues have now come to the forefront. The purpose of this research, therefore, was to assess different stakeholders in Tofino to understand impacts of tourism development in Tofino as well as to identify possible solutions for long-term sustainable development through a multi-stakeholder assessment. Research was conducted with 38 key stakeholders in the summer of 2009 to help the community understand key issues facing their future.
\end{abstract}

Keywords: sustainable tourism, Tofino, Canada, community, island tourism, economic diversification

\section{Introduction}

Many destinations worldwide have recognized the potential contribution of tourism in overcoming economic disparities. A significant number of these destinations are islands that are now dependant on tourism for their livelihood as a deliberate diversification away from other industries to international tourism has helped them prosper. Tofino, Canada, is home to a population of approximately 1,655 residents (Tourism Tofino, n.d). Although there is still some resource extraction such as aquaculture and proposed mining in the area, tourism is now the main income source. Tofino is world-renowned as a vacation hotspot, noted for its spectacular views, endless surf, lush rainforest, and close proximity to the Pacific Rim National Park Reserve. Located on the southwest coast of Vancouver Island, adjacent to the Clayoquot Sound UNESCO Biosphere Reserve, Tofino has become a popular tourist destination and accommodates upwards of 1 million visitors per year (note). The town's population of about 1,700 people can swell to 20,000 on a busy summer weekend (District of Tofino, 2009), greatly increasing the demand placed on the town's resources during these peak summer months. Whale and bear watching are popular ecotourism activities, its adventure activities are growing and its long sandy beaches are an increasing draw for surfers.

The largest growth in tourism was in the mid 1980s with outdoor activities such as whale watching becoming popular. With the contentious Clayoquot Sound Land Use Decision in 1995 that aimed to disrupt the logging industry, this also saw the beginning of a major increase in tourism demand in the area. New businesses developed focusing on adventure and ecotourism as well as restaurants, coffee shops, retail opportunities and accommodations. From the late 1990 's to the beginning of the $21^{\text {st }}$ century, there was an advent of many wealthy visitors and residential developments, bringing with it affluent tourists. Tofino, which started as a remote, fishing village, has repositioned itself as an international tourism destination. Amenities have increased from 10 years ago and Tofino now attracts both regional and international visitors. Although the recession has seen a dip in visitation in the summer of 2009, there is no concern that this is a long-term problem as this has shifted the visitor base from international to regional with an increase in visitors from Western Canadian and Northwestern America. 
This paper seeks to explore the current situation and recommendations for the future development of Tofino through a multi-stakeholder process. It builds upon previous research conducted by Welk (2006) and by Dodds \& Basu (2008). The aim of this paper therefore is to examine stakeholder theory and resource dependence theory as it applies to a tourism destination with a key focus on water as it is a vital resource for successful tourism. Additionally the stage of life cycle of the tourism destination as well as the concept of Limits of Acceptable Change is discussed to provide context.

\section{Literature Review}

\subsection{Theories: Tools to Manage?}

As many authors and government reports have outlined (Brigugulio et al., 1996a; 1996b; Weaver, 2001) and recent events (hurricanes, tropical storms, and Tsunamis) have demonstrated, there is a need to move towards more sustainable forms of development and implement sustainability practices within destinations to ensure long term viability. Many islands depend heavily on the natural resources of an area and it is these resources that their industries have traditionally been based upon. As the sustainability of many destinations economies is now dependant on tourism, the need for planning and management of a destination is imperative. Dodds and Butler (2009), referencing multiple authors believe that sustainable tourism is the responsibility of all stakeholders and if so, there is a need to understand stakeholder roles and their role in sustainable tourism practices. Stakeholders are defined as any individual or group who can affect the firms' performance or who is affected by the achievement of the organization's objectives (Freeman, 1984). In a tourism context, Sautter and Leisen (1999) and Bansal and Roth (2000) outline that stakeholders consist of residents, management, government, activist groups/NGO's, employees, tourists and industry associations. Stakeholder management can be a useful way of organizing as it can respond to the concerns of stakeholders because those stakeholders can ultimately affect the plans and activities of the firm (Husted, 1989). The organizational setting of a firm can be similar to that of a destination as destinations are also bunches of resources just like companies (Ryan, 2002). For the long-term viable management of a destination, is important to understand the views of stakeholders as they can motivate or impede sustainability in organizations (competitive advantage, regulatory compliance, economic considerations, etc.) (Graci \& Dodds, 2008; Bansal \& Roth, 2000; Carroll, 2000; Lantos, 2001).

Some destination studies have identified motives and barriers to sustainability such as economic considerations, political power and salience, coordination between stakeholders, accountability of all stakeholders, lacks of will and integration between government bodies (Ioannides, 2001; Dodds, 2007a; 2007b). These studies, although defining barriers to achieving more sustainable tourism practices, have not evaluated stakeholders on their level of practices.

Another theory that is useful to consider in managing a destination is Resource Dependence Theory. Pfeffer and Salancik (1978) stated, "to understand the behavior of an organization you must understand the context of that behavior-that is, the ecology of the organization." As with stakeholder theory understanding all stakeholders is imperative. This theory is based on the idea that environments are made up of scarce resources and organizations are dependent on these limited and finite resources for long-term viability. A lack of control and management over these resources results in uncertainty for firms operating in that environment (Pfeffer \& Salancik, 1978). In a tourism destination, this theory could also apply - as the very resources that attract tourists must be maintained to ensure their attractiveness. For example, hotels are dependent on electricity and water resource and therefore, in order to reduce the impact environmental uncertainty on organizational performance, it is necessary for organizations sustain their external environment. Strategic choice and environmental determinism do not have to be mutually exclusive.

The theory of the destination life cycle model (Butler, 1980) has been used to describe the tourism development process in many tourism destinations and can also be applied to this case study. According to the life cycle of a tourist destination (Butler, 1980), destinations must be planned accordingly so that they will maintain their attractiveness rather than lose their appeal or become over-saturated and enter into the decline stage. Sustaining a destination does not just depend on economic considerations but also environmental and social ones. The life cycle model describes six stages of an evolutionary sequence that a tourist area passes through: exploration, involvement, development, consolidation, stagnation and rejuvenation or decline. The life cycle outlines, that as airports, accommodation and other tourist facilities are provided, awareness grows, but visitors will eventually decline as capacity is reached. Each stage is accompanied by changes in the nature and extent of facilities provided and the local/non local provision of these. The life cycle approach can be applied to a micro level for the specific resort, or to a macro or regional scale and is therefore put forth as a useful tool to establish at what stage of development an island's tourism development may be at. 
Limits of Acceptable Change is a management tool for setting limits or managing tourism are assessing carrying capacity, or developing indicators for tourism optimization. Limits of Acceptable Change (LAC) attempts to assess stress in both the natural and social and economic environment and to define the maximum degree of change that is tolerable. Identifying limits of acceptable change is a management practice developed put forth a composite set of policy criteria including a 'sustainability first' decision rule or a 'safe-minimum-standard'. Such techniques that focus on environmental and social protection or environmental impact assessments offer economic benefits at the early stages of project formulation such as the improvement in design and siting of plans, savings in capital and operating costs, speedier approval of development approval and avoidance of costly adaptations to the plant once it is established' (Green \& Hunter, 1992).

\subsection{Tourism Development in Tofino}

In order to assess stakeholders, first the context of Tofino according to its lifecycle (Butler, 1980) is useful to explain. Tofino is an internationally recognized destination due to its proximity to Pacific Rim National Park as well as its beautiful beaches and outdoor vistas. During the 1960's surfers and hippies were drawn to the area due to a logging road opening in 1959. In 1971, the Pacific Rim National Park was established and served to attract visitors as well as the movement of homes and businesses from Long Beach to Tofino (Welk, 2006). Tourism numbers have grown substantially and tourism is the main economic contributor to the livelihoods of the community. In 2007, the Tofino-Long Beach Chamber of Commerce estimated the number of visitors to approach totals of almost 35, 000 visitors and these tourists brought in an economic value of approximately 50 million dollars per year (CTV.ca News Staff, 2006). Tourism numbers, however, have started to even out and although there was a dip in numbers due to the recession of 2008/9, visitor numbers are also seen to be shifting into other markets. To counter this, since 2006, Tofino has undertaken the Community Planning Process provided through Tourism BC. There is also current activity to brand Tofino as a collective with other destinations to become 'West Coast Vancouver Island' and Tofino and Uquelet are working together to cooperatively market the region (personal communication, Tofino Chamber of Commerce, July 2010). These initiatives, however, have focused on marketing efforts rather than assessing resource or other livelihood issues. From a lifecycle analysis, Tofino is in a maturity state from a room night perspective but has faced decline in terms of its resource infrastructure relating to capacity.

As the rapid growth of tourism within the last few decades have resulted in numerous facilities such as increased infrastructure in and around Tofino, this has often resulted in negative social and ecological impacts such as the lack of adequate infrastructure to cope with garbage and sewage, isolation or lack of adequate community facilities and disruption to livelihoods due to the cost of living. In addition, according to the provincial government, the region has been experiencing drier than normal conditions. Consequently, Tofino has been experiencing seasonal water shortages in recent years which is a major issue considering the dependency of tourism on water for both hosts and guests. For example, in the summer of 2006, the District of Tofino placed a ban on commercial water use and the town ordered a shut down due to a combination of heavy demand and a shortage of rain (CTV.ca News Staff, 2006). Even though Vancouver Island's west coast and Tofino specifically, is considered a rain forest, the year-round population of about 1,700 , grows substantially in the summer months - at times reaching over a population of 20,000 per day (CBC News, 2006). Water was so scarce that there were concerns about whether there would be enough available to fight a fire in the town (CBC News, 2006). In 2009 there was another water shortage, however, most residents were aware that this was storage rather than a shortage issue but there was consensus that this issue should have already been dealt with and there was frustrating about lack of attention to a problem which was so important to the livelihoods of all businesses as well as residents.

Understanding the role of different stakeholders and what their views are about tourism development in the area and benefits and challenges may assist in determining the future management of a destination such as Tofino. It was therefore the purpose of this paper to assess different stakeholders views as well as current practices and concerns about sustainable tourism.

\section{Methodology}

The purpose of this research was to examine different stakeholder perspectives of tourism in Tofino in order to determine impacts and challenges relating to tourism development and long-term sustainability. The study determined whether stakeholders were in consensus surrounding future tourism planning or policy development. Semi-structured stakeholder interviews were held with 38 stakeholders in August 2009. First, key informants were decided upon to ensure a wide stakeholder group was represented. Through a snowball sampling approach, additional stakeholders were interviewed until the same names were provided, thus ensuring ample information was gathered and there was adequate representation of interest groups. Interviews obtained included local 
government officials including the Mayor of Tofino and the local planning and parks authority, land developers, NGO's, long time residents, businesses (retail shops, restaurants, bars, surf shops, tour operators, B\&B's, hotels) and indigenous $1^{\text {st }}$ Nations leaders.

Stakeholders were first asked about tourism in Tofino and to describe in their own words if they felt it had changed over the years and if so, how. They were then asked if there were any impacts (both positive and negative) in order to gain an understanding of the current condition of tourism and stakeholder satisfaction with the destination's management. Respondents were then asked about what stage of the lifecycle they felt Tofino was in and if there were any challenges that Tofino was facing. Respondents were also asked to identify what practices that were taking place - either their own or ones they knew of to address any challenges they had noted. Questions about whether consumer demand was shifting were also asked. Finally, management implications were discussed. Stakeholders were then asked about the role of stakeholders and who they felt should be responsible for managing and governing tourism development in Tofino. This discussion was held in conjunction with a discussion of current policies and planning that were taking place. Finally each stakeholder was asked what they would do if they were in charge of long-term tourism management in Tofino. Interviews were approximately 45 minutes to one hour in length. From the identified 45 key informants names that were given to the researcher, 38 interviews were obtained.

Respondents were also asked about climate change as Tofino is located on an island coast and could be threatened according to international research. Bowes et al. (2007), Gössling, et al. (2005), Hall and Highman (2005), Peeter et al. (2007) and Scott et al. (2005) note that climate is a major determinant of the characteristics of ecosystems, its rapid change will result in habitat change and loss. Issues such as water shortages, increased hazards, erosion and flooding are all possible.

As part of the process of this research, responses from stakeholder interviews were sent back to all respondents in Tofino as one compiled document outlining all issues and challenges as well as suggestions for moving forward. The purpose of this process was to ensure responses were representative and to also provide a cohesive document to the local government for future planning initiatives. Inputs received from this process showed that all stakeholders agreed that the collaborative findings were a fair representation of all stakeholders' views.

\section{Findings}

\subsection{Stakeholder Views about Tourism in Tofino}

Stakeholders were divided about the benefits of tourism. About half felt that tourism, although a good livelihood for tourism business owners, does not give back to the community and the sense of place is in jeopardy. The other half felt that residents do not understand the value of tourism and that tourism provided a much-needed future when fishing and mining ended.

Although doing well in terms of tourism numbers, all stakeholders noted that Tofino is limited by land area and is constrained by current infrastructure. Tofino is an island location and is serviced by one road into town. It is also located on the west coast of Vancouver Island and is approximately $206 \mathrm{~km}$ (128 miles) from the nearest international airport and large town (Nanaimo). Tofino is still growing and new developments are slated for construction. New hotels and condos are still being constructed but they are now limited by space and zoning designations which prohibits building in some areas and limits density. Due to these restrictions, the destination is felt to still be in the development cycle of the destination life cycle, however, many locals and businesses believe that it is reaching maturity as a tourist destination. Many respondents believed that Tofino had reached its capacity of accommodation, restaurants and tour operators but that there was an opportunity for other businesses, especially ones that would support the resident base as well as the tourists. Due to the timing of the interviews (during the water shortage of 2009), all respondents mentioned resource dependency and concluded that although it was needed, there have been little, if any, discussions for more sustainable tourism.

\subsubsection{Economy}

Some stakeholders were concerned that Tofino is becoming a monoculture of tourism and that it is highly vulnerable to outside influences (e.g. competition, environment disaster such as a mudslide or road closure due to one road access). Tofino is also highly seasonal and although the increased success of Storm Watching has been beneficial for addressing seasonality in Tofino, approximately $50-80 \%$ of revenues are still made in the summer months of July and August. As many island destinations, Tofino must transport in many of its resources such as large quantities of food and raw materials. Respondents were aware of the limited accessibility and noted leakage as a challenge as many services are not provided in Tofino. 


\subsubsection{Capacity/Infrastructure}

All respondents noted that infrastructure is a major challenge that faces Tofino and that tourism has been promoted without supporting the infrastructure needed for growth. With such high visitors numbers, infrastructure is in need of updating, however, with a low permanent tax base, the cost of fixing outdated infrastructure is of high concern.

- Water: In response to the water shortage issues of 2006 a joint federal, provincial and municipal water system improvement project, expected to cost \$6-million, was scheduled for completion by the following year. The Public Works Superintendent devised a six-stage Water Shortage Response Plan. A Tofino Water Upgrade Project was also devised, involving the building of a reservoir at the stump dump and the construction of a new water main, and was slated for March 2006; however, the following summer saw the threat of business closures and a water ban due to dangerously low main reservoir water levels and no progress on infrastructure improvement. Fortunately businesses were permitted to stay open and the water ban was lifted, but with major water restrictions, as water was trucked in from nearby Ucluelet. An additional million-gallon reservoir was added to the south end of the district at the stump dumpsite by the summer of 2007 and was online as an emergency backup. The new tank was awaiting a re-chlorination plant for it to be online permanently and fully functional, which was expected to be completed by August or September. Two years later, a new four-stage Water Shortage Response Plan was devised as the existing six-stage one was proving to be ineffective. In addition, a new water main was in place and the expansion of the Ginnard Creek Reservoir was underway to create the Ahkmahksis Reservoir, expected to have a capacity of 10-million gallons upon completion.

In the summer of 2009 , the updated 4-stage water shortage response plan was adopted and stage 2 water restrictions were in place in Tofino in response to yet another water shortfall. The 1-million gallon Stump Dump tank was online and the Ahkmahksis Reservoir was expanded to a 5-million gallon storage facility; however, water from the expanded tank was non-potable as the town was still awaiting a treatment plant. On July $21^{\text {st }}, 2009$, the Tofino Town Council approved the construction of a $\$ 1.1$ million water treatment plant for the newly expanded reservoir that was expected to be online by summer 2009. Although this could mean a possible end to the town's water woes, there is concern over the high operating costs of the plant and the district has only budgeted to use the plant for 2 months out of the year for the next 4-5 years. Further fuelling the residents' water worries, on August $4^{\text {th }}$ the council announced that there would be an increase in water rates in an attempt to cover the district's 2009 operational water budget shortfall of $\$ 353,824$. According to the new rate scheme, residents should expect increases of about $58 \%$ on their water bills.

- According to the District Treasurer, Edward Henley, the District has not contributed to infrastructure reserve funds since 2000. Moreover, the district has found itself in somewhat of a catch twenty-two for as water conservation has been urged among residents and businesses during the water shortages, the amount of money coming in to assist with water improvement has decreased. In response to the current water deficit, Councilor Stephen Ashton suggests that commercial sector should bear the brunt of necessary rate increases, as residential costs are already high enough in Tofino. In addition, Mayor John Fraser has noted the importance of looking to long-tem borrowing for future projects.

- Sewage: There is currently no sewage treatment plant and raw sewage is pumped into the ocean. Although there are strong currents where current sewage is being expelled, with the high numbers of visitors in the summer, untreated sewage has become a concern.

\subsubsection{Governance}

There is major concern over bureaucratic governance and the length of time to make decisions. This was discussed in relation to the 2006 and 2009 water shortages. Although the general consensus is that governance is less self-seeking than the past, most stakeholders noted there is a lack of strong leadership and monies have been diverted for research studies or to engineering firms rather than infrastructure maintenance. There is also concern that the District is focusing too much on micro issues (such as zoning bi-laws) rather than preparing a much needed Master Plan for the region. All stakeholders are aware of the problems of multiple layers of governance for land use issues. Although there are concerns over lack of governance, most stakeholders did note that there has been a recent history of staff turnover of city planners and Chief Administrative Officer that have caused many issues with developers and misguided planning.

\subsubsection{Development}

From the 1960's and 1970's, Tofino was dominated by a small number of families, who now own large amounts of land and have a large share of influence of tourism development in Tofino. There is concern among the main land owners as well as other residents that Tofino is losing its sense of community and although there is no fear that it 
will become a mass scaled resort due to location and weather, there is increasing evidence that the fabric of the community is changing. Property and land value, especially property lining the beaches, have skyrocketed and many young families are leaving as there is a lack of affordable housing (due to zoning restrictions of the Official Community Plan and the changing nature of the tourism industry (e.g. many employees are seasonal and salaries in tourism are low compared to that of mining and fishing)). There is also a perceived lack of amenities for the community (schools, recreation facilities). Property prices and taxes, although perceived to be high, are not significantly different than other urban areas but are important to note as there is a low tax base that greatly affects the income back for repairing infrastructure etc..

\subsubsection{Community Benefits}

Although there are some seasonal tourism issues such as parking, longer lines and increased garbage, many understand that this is seasonal and that the costs of these inconveniences are outweighed by the benefits of tourism dollars. Some respondents did note that development monies have often been one offs rather than benefitting the community. For example, developments historically have not provided any planning gains or concessions to the District and apart from a few examples (e.g. new Cox Bay resort said to be providing money to council for the improvement of amenities), most developments do not contribute to long-term operational costs (e.g. garbage collection, infrastructure repairs and maintenance). There is also a concern that there is a lack of community infrastructure (e.g. recreation centre) and that monies are being spent on tourism facilities rather than the community (e.g. public washrooms).

\subsubsection{Second Homes}

There is increasing concern over second homes being illegally used as accommodations and staff housing. There is currently no regulation to limit the number of beds in vacation homes. It is estimated that $40 \%$ of housing in Tofino is second homes. Forty six percent of all properties (not just residential) have a mailing address outside of Tofino for the property tax bill. There is also a concern that $\mathrm{B} \& \mathrm{~B}$ and second homes are providing tourist accommodation but not contributing taxes.

\subsubsection{First Nations Treaty Negotiations}

Residents are regarded as the rightful custodians of an area and their needs should not be overridden by outside interests (Veitayaki, 2006). Although in many tourism destinations there is often strife between the local indigenous people and the tourism developers, this is not the case in Tofino. Two of the main First Nations groups in the area have hotels and tourism amenities and have good relationships with other stakeholders. The only issue is that the First Nations proposed mining on Cat Face Mountain and fish farming agreements may threaten Tofino's natural image and therefore tourism. As much of the area surrounding Tofino is First Nations land, decisions on the upcoming Treaty may threaten Tofino and are of concern to the long- term sustainability of tourism.

\subsubsection{Conservation}

When discussing wildlife management and park management (as Tofino is heavily dependant on the Pacific Rim National Park on which it borders), respondents noted that overall animal and park conservation was well managed. For tour activities such as whale and bear watching, there was agreement that most operators respected Marine Viewing Guidelines and worked together to ensure the well being of mammals. There was, however, some concern over the increase in garbage bears due to beach areas overflowing with garbage from high use.

\subsubsection{Transport}

There is ongoing discussion about developing Tofino airport and there are some fears that there is currently inadequate infrastructure at the airport and that the town would not be able to cope with the extra strain on existing infrastructure. Tofino also only has only one road into town and there are fears that this access is vulnerable and could harm Tofino should it be jeopardized. Public transportation is an issue due to the population and development being spread out and usage is low. In addition, having a car is a necessity due to little transport as well as distances. Most tourists arrive by car, thereby adding to this strain.

\subsubsection{Labor}

There is a skilled labor shortage and with the advent of tourism, many staff are unskilled. Low pay is also a concern in that the 'Valet' may have to work two jobs in order to sustain his/her livelihood and therefore, does not contribute to volunteering which is essential for such a small community (e.g. volunteer fire service). As with many island or small communities, seasonality is also an issue as jobs are often only for a few months of the year and this encourages a transient population. 


\subsubsection{Media}

The latest water shortage was covered extensively by media which has highlight the power that media has over the image of Tofino and stakeholders are concerned that this could affect its historically good image. Although the Tofino Tourism Association was created, there are no specific media releases to alleviate tourist fears over shortages or beach issues and therefore residents feel that their image may be at risk.

\subsection{Tofino's Future?}

The past 2006 and 2009 water issue brought sustainability issues to the forefront of tourism development and management in Tofino. Awareness of the sustainability of tourism has increased, however, many stakeholders perceive tourism to be a clean industry and are only recently noticing the negative impacts from tourism. Overall the perception by many in Tofino is that it is an eco community, however, many efforts are piecemeal or individual attempts to become more environmentally responsible rather than developing and managing the destination in a more sustainable manner.

Some stakeholders are making substantial efforts (geothermal, complete organic/fair-trade purchasing) but this is not widespread, nor part of policy or governance. Only recently, with the 2009 water shortage, did the Council, in partnership with Tourism Tofino, act to pass out literature about water conservation and actively monitor use. This educational initiative was seen by many respondents as innovative, however it should be noted that conservation of water and energy is standard practice year-round in most accommodations worldwide.

Change is incremental but some practices are taking place and should be highlighted:

- Water: There have been some efforts to install low flush toilets and conserve water but not all stakeholders are taking part. Most efforts were only in response to water shortage rather than standard practice. Some efforts have been made during water shortage to educate the visitor and regular water monitoring.

- Waste: There has been an increased local sourcing of food. Many establishments offer biodegradable take-away containers and biodegradable cleaners. Recycling efforts are slowly growing although limited. Some larger hotels have composting facilities. Some larger hotels are actively trying to find ways to reduce waste and compost.

- Energy: There is little widespread action, however, the First Nation Ahousaht's new housing development and Pacific Sands Resort have made substantial geothermal efforts and new buildings are starting to adhere to a green building code. There are some limited energy efficiency measures and there is a District pilot project set to examine solar energy. Most boating operators have made efforts to reduce fuel consumption and switched to four stroke engines and/or biodiesel.

- Local sourcing: Most establishments in Tofino are moving toward locally sourced products and food. Substantial efforts have been made toward fair trade and organic purchasing, especially based on Tofino's remote location. A current healthy food/healthy community's initiative and 'green breakfast initiative' is underway whereby many local businesses and residents are attending workshops on local food production and food security. Community gardens are now part of some First Nations community plans. Due to the isolated location in Tofino, some businesses felt it is difficult and therefore limited practices are undertaken (mainly recycling, increased low flush toilets and use of eco cleaning products).

- Public transport: There is one public bus, however, public transport is not widely promoted by businesses nor widely used by locals and tourists. Currently the surf community and backpackers are the most frequent users of public transit. Many surf schools carpool to the beach.

- Education: Apart from the recent water conservation initiative, there is little education to visitors about sustainability practices.

When asked about consumer responses and whether demands have shifted towards more eco forms of travel, respondents thought that visitors were more eco -conscious. Due to the history of logging and environmental concern in Tofino (Clayoquot Sound Land Use Decision), most residents are aware of the environment, however, there is confusion over visitors who like the outdoors and those who are demanding more sustainable practices by businesses. Evidence from respondents also outlined that 'eco' conscious visitors expect more sustainable practices but do not necessarily make decisions based solely on these factors. It was noted that European visitors are more demanding for environmental practices than other tourism groups.

All respondents were aware of the impacts and effects of climate change globally, however, there is little day-to-day concern in Tofino. Awareness of climate change rose when the incident of Humboldt squid washed up on the beach (summer 2009) and food sources for whales have shifted, however, no real concern is evident. As one 
respondent (\#5) noted, "If people were concerned about climate change, they wouldn't be buying million dollar homes on Chesterman beach". From all stakeholder interviews, there has been an increased awareness of issues such as energy and water shortages, however these were not attributed to climate change and property prices along beachfronts have remained high. There have been some efforts, however, and some businesses and government agencies were more concerned than other stakeholders. Some businesses have calculated their carbon footprint through an initiative started by Carbon Trust and government has passed an anti-idling bi-law. These initiatives are not necessarily to deal with tourism development issues but rather in response to Provincial pressures.

When asked about who should be responsible for managing tourism in Tofino, almost all stakeholders felt that tourism management should primarily be the concern of local government. Suggestions for a partnership between the District, Chamber of Commerce, Tourism Business Association and Tourism Tofino were also noted as Tourism Tofino was currently undertaking marketing efforts and they had taken a leadership role in education during the water shortage in 2009.

\section{Discussion}

Tofino, as an island destination is generally more susceptible to negative impacts of development as it has limited natural and social resources. From a resource dependence perspective, Tofino is at a critical stage of its lifecycle in that the very elements that attract tourists are dependent on its natural and build resources. Water shortages, sewage treatment, transport and housing are issues that have reached a critical point and are now affecting all stakeholders in the area and respondents from this study were aware that this soon could also impact visitation. Tofino, although growing, has reached a critical position in its lifecycle where many challenges of growth are being felt. Property and land value, especially lining the beaches, have skyrocketed, forcing some local residents to leave (Welk, 2006; Dodds \& Basu, 2008). The media has outlined a number of issues that has drawn a negative focus on Tofino. Tofino has also recently faced two water shortages. As the sustainability of many destinations economy is now dependent on tourism, destinations will need to maintain their attractiveness so as not to enter into the decline stage (Butler, 1980).

An explanation of Tofino's tourism development and current lack of infrastructure and planning could be that the life cycle of Tofino hasn't reached saturation and is still in the growth stage (Butler, 1980). As tourism usually tends to be reactive rather than proactive - until negative effects actually affect tourism numbers, sustainability measures will not be put into place (Dodds \& Basu, 2008). Eventually the quality of the tourist experience is reduced and a destination's comparative natural/unique/real advantage is lost or reaches a decline. Butler points out that tourism is an activity that, because of its reliance upon the maintenance of natural environment and natural processes, should lend itself toward sustainable development (1993). In the case of Tofino, the pressure on natural resources are beginning to become evident but the tourism economy is not suffering to date and visitor numbers are still increasing. In order to move towards more sustainable tourism, holistic planning for a destination needs to occur. To date, this has not been the case as demonstrated by Vodden (2003) who commented on Tofino's development.

"Movement towards ecotourism as the focus for the Region has not been a conscious or coordinated decision on the part of local governments or other agencies. Rather it has grown organically out of individual business owner assessments of the type of visitors attracted to the area and the subsequent shaping of tourism products...the absence of tourism development strategy is evident."

When examining stakeholder theory, this study agreed with Hardy and Beeton (2001) in that it is important to understand stakeholder perceptions in facilitating more sustainable development of tourism. From a governance structure, the current governing document for Tofino is the Official Community Plan (OCP), however, it is out of date and is more of an overarching planning document rather than a strategy for achieving more sustainable tourism. This finding supports recent findings by Dodds and Basu (2008) in that there is no overarching plan for a different model of tourism and no strategies or specific promotion of sustainable tourism practices for visitors or businesses to follow which may help alleviate infrastructure and social pressures. This research found that since no stakeholder group is taking the lead to move the destinations towards more sustainable development practices, this may relate to the reason that there is no updated tourism development plan nor any references to sustainable forms of tourism. Stakeholders believe that Tourism Tofino may have the opportunity to play more of a leading and influencing role in this regard. All stakeholders noted that Tofino does have an Official Community Plan (OCP) and that it is a good, if outdated document.

From this study, several similarities exist between resource dependence theory and stakeholder theory, as they both recognize the firm (destinations) interdependence on external and internal contingencies (Hillman et al., 2009) and who takes precedence in a situation (Mitchell et al., 1997). For tourism to survive in Tofino, long term 
planning and considerations for sustainability need to be implemented if this island destination is to maintain its appeal. As this study attempted to solicit stakeholder views in order to determine a collective vision for moving forward, the following are a list of aggregated recommendations. First, a cohesive and comprehensive plan, which includes planning for long-term development, is needed. The current Official Community Plan needs to be updated with input from all stakeholders and natural and social resources considered in the planning process. Secondly, there is the need to identify and define Limits of Acceptable Change to govern for the long-term sustainability of Tofino through a Master Plan. Third, Tourism Tofino as the key marketing and promotional agency, and one that represents many tourism business interests, should play a representative role for businesses in the governance and development of tourism. This would provide one comprehensive tourism voice and maintenance issues to ensure that the image of Tofino (as an outdoor beautiful destination) is upheld. This is not to say that they should be the only voice for planning. All stakeholders need to be brought together (including First Nations) to create an integrated vision for tourism that recognizes 'sense of community'. This visioning process, which would be a multi-stakeholder process, would perhaps ensure that a wider view of tourism development is incorporated moving forward. Fourth, there is a need to generate income for infrastructure and livelihood requirements for the residents of Tofino. One possibility is to establish amenities payments for new developments. This could be in the means of planning gains - additional monies charged to developers to be allocated towards infrastructure and operational costs rather than once off costs such as a new trail or washroom. It is estimated that $10 \%$ of all capital costs are needed for upkeep of facilities for every year of their lifespan. Fifth, there is a need to diversify industries to attract year round businesses and professionals.

Overall, the key outcome of stakeholder consultations is that tourism development for Tofino cannot only be based on economic returns and visitor numbers. Environmental and social considerations need to be considered for future viability of tourism (e.g. the need to look at affordable housing). As Hillman et al. (2009) point out, "perhaps combining recent resource dependency theory recognition of the multiplexity of dependencies with the insights from theory regarding stakeholder importance would yield greater insights for managing dependencies and the specific strategies to do so" (p. 1417).

\section{Conclusion}

This research supports other studies in that the natural appeal of an island, as in any destination, is typically one of its main tourism related assets, yet the natural environment is also the feature most directly threatened by potential overexploitation (Murphy, 1995; Butler, 1993; 1998). For Tofino, sustainability has now become a necessity rather than just a hope. As there are several demands from stakeholders that motivate or impede sustainability (Bansal \& Roth, 2000), these demands now must be met in order to move towards successful management of tourism in Tofino.

From this study, many stakeholders believed that they had differing viewpoints on issues and that power struggles existed between the Tofino council, community and businesses, which they believed was the reason that some issues had not been corrected. After interviewing a wide range of stakeholders representing the different interest groups in Tofino, a different conclusion was drawn. This study found that most stakeholders discussed the same issues and although differed on their views of how tourism benefitted the town, all were in agreement that a long term vision and management strategy needed to be put forth and that although not always termed sustainability (rather infrastructure, livelihoods, community well-being, etc.), all stakeholders including NGO's and residents recognized that the industry was dependent on external elements that they needed to take more control of. From a destination management perspective, it was agreed that the local council should take precedence for the long-term longevity of the industry.

\section{References}

Bansal, P., \& K. Roth. (2000). Why companies go green: A model of ecological responsiveness. Academy of Management Journal, 43(4), 717-736. http://dx.doi.org/10.2307/1556363

Butler, R. W. (1980). The Concept of a tourist area cycle of evolutions: Implications for management of resources. Canadian Geographer, 24(1), 5-12. http://dx.doi.org/10.1111/j.1541-0064.1980.tb00970.x

Butler, R. W. (1993). Tourism - an Evolutionary Perspective. In J. G. Nelson, R. Butler, \& G. Wall (Eds.), Tourism and Sustainable Development: Monitoring, Planning and Managing 37. University of Waterloo: Waterloo, Department of Geography Publication.

Butler, R. W. (1998). Sustainable Tourism - Looking Backwards in Order to Progress? In C. M. Hall, \& A. Lew (Eds.), Sustainable Tourism: A Geographical Perspective (pp. 25-34). Harlow: Longman. 
Carroll, A. B. (2000). The four faces of corporate citizenship. In Richardson, J. E. (Ed.), Business Ethics 1 (1). Dushkin/McGraw-Hill, Guildford, CT, pp. 187-191.

CTV.ca News Staff. (2006, September 1). Tofino mayor gives OK for businesses to stay open. Retrieved from http://www.ctv.ca/servlet/ArticleNews/story/CTVNews/20060901/tofino_folo_060901/20060901?hub=Top Stories

District of Tofino. (2009, September 8). Retrieved from http://www.tofino.ca/siteengine/activepage.asp

Dodds, R. (2007a). Malta's Tourism Policy - Standing Still or Advancing Towards Sustainability? Island Studies Journal, 2(1), 44-66.

Dodds, R. (2007b). Sustainable Tourism \& Policy Implementation: Lessons from the Case of Calviá, Spain. Current Issues in Tourism, 10(1), 296-322.

Dodds, R., \& Basu. S. (2008, October 15-17). Is Change a Constant? An Assessment of Stakeholders Participation in Sustainable Tourism Practices in Tofino, BC. TTRA Canada Conference, Victoria, B. C.

Dodds, R., \& Butler, R. W. (2009). Inaction More Than Action: Barriers to The Implementation of Sustainable Tourism Policies. In S. Gössling, M. Hall, \& D. B. Weaver (Eds), Sustainable Tourism Futures (pp. 43-57), London: Routledge.

Freeman, E. R. (1984). Strategic Management: A Stakeholder Approach. Boston: Pitman.

Getz, D., \& Timur, S. (2005). Stakeholder Involvement in sustainable tourism: balancing the voices. In Theobald, W. F. (Ed.), Global Tourism (pp. 230-247). London: Elsevier. http://dx.doi.org/10.2167/cit278.0

Gössling, S., Peeters, P. M., Ceron, J. P., Dubois, G., Patterson, T., \& Richardson, R. B. (2005). The eco-efficiency of tourism. Ecological Economics, 54 (4), 417 - 434. http://dx.doi.org/10.1016/j.ecolecon.2004.10.006

Government of British Columbia. (2005). Snow Survey Bulletin, Snowpack and Water Supply Outlook. Retrieved from http://www.env.gov.bc.ca/rfc/archive/index.html (accessed September 10, 2009).

Graci, S., \& Dodds, R. (2009). Why go green? The business case for environmental commitment in the Canadian hotel industry. Anatolia: An International Journal of Tourism and Hospitality Research, 19(2), 250-270.

Hall, C. M., \& Higman, J. (2005). Tourism, Recreation and Climate Change. UK: Channel View Publications.

Hansen, D. (2006, September 1). Uclulet Goes - And Grows - With the Flow. Victoria Times Columnist. Retrieved from http://www.ucluelet.ca/docs/090106_TC_UKEE.pdf (accessed September 18, 2009).

Hardy, A. L., \& Beeton, R. J. S. (2001). Sustainable Tourism or Maintainable Tourism? Managing Resources for More than Average Outcomes. Journal of Sustainable Tourism, 9(3), 168-192. http://dx.doi.org/10.1080/09669580108667397

Hillman, A. J., Withers, M. C., \& Collins, B. J. (2009). Resource Dependence Theory: A Review. Journal of Management, 35(6), 1404-1427. http://dx.doi.org/10.1177/0149206309343469

Ioannides, D. (2001). Sustainable development and shifting attitudes of tourism stakeholders: Toward a dynamic framework. In S. F. McCool, \& R. N. Moisey (Eds.), Tourism, Recreation and Sustainability: Linking Culture and the Environment. Oxon, U.K.: CABI Publishing.

Jamal, T., \& Getz, D. (1997). Visioning for Sustainable Tourism Development: Community Based Collaborations. In P. Murhpy (Ed.), Quality of management in Urban Tourism. Chisteter: Wiley.

Lantos, G. P. (2001). The boundaries of strategic corporate social responsibility. Journal of Consumer Marketing, 18(7), 595-630. http://dx.doi.org/10.1108/07363760110410281

Mitchell, R. K., Agle, B. R., \& Wood, D. J. (1997). Toward a Theory of Stakeholder Identification and Salience: Defining The Principle of who and What Really Counts. Academy of Management Review, 22(4), 853-886.

Peeters, P. (2007). Mitigating tourism's contribution to climate change - an introduction. In Peeters, P. M. (Ed.), Tourism and climate change mitigation. Methods, greenhouse gas reductions and policies, 11-26. Breda: NHTV.

Pfeffer, J., \& Salancik, G. R. (1978). The external control of organizations: A resource dependence perspective. New York: Harper \& Row.

Ryan, C. (2002). Equity, Management, Power Sharing and Sustainability - Issues of the 'New Tourism'. Tourism Management, 23(1), 17-26. http://dx.doi.org/10.1016/S0261-5177(01)00064-4 
Sautter, E. T., \& Leisen, B. (1999). Managing stakeholders. A tourism planning model. Annals of Tourism Research, 26(2), 312-328. http://dx.doi.org/10.1016/S0160-7383(98)00097-8

Scott, D., Jones, B., \& Abi Khaled, H. (2005). The Vulnerability of Tourism in the National Capital Region to Climate Change. Technical Report to the Government of Canada's Climate Change Action Fund (Impacts and Adaptation Programme), Natural Resources Canada. Waterloo, ON: University of Waterloo.

Times Colonist. (2009, July 19). Outdoor water use banned in Tofino. Retrieved from http://www.timescolonist.com/life/Outdoor+water+banned+Tofino/1805864/story.html

Tourism Tofino. (2011, October). Retrieved from http://www.tourismtofino.com/travel-info/faq/

Veitayaki, J. (2006). Caring for the environment and the mitigation of natural extreme events in Gau, Fiji islands: A self-help community initiative. Island Studies Journal, 1(2), 239-252.

Vodden, K. (2003). The Clayoquot green economic opportunities project: Taking steps towards a conservation economy (Monograph). Retrieved December 14, 2007, from The Friends of Clayoquot Sound Web site: http://www.focs.ca/reports/GreenEconVol2.pdf

Welk, E. J. (2006, Fall). The evolution of a coastal community: Power relations and tourism geographies in Tofino, British Columbia (Rep. Master of Arts Thesis). Simon Fraser University, Department of Geography.

Vancouver Sun. (2006, Aug 13). Visitors to Tofino face \$5 parking fee. Retrieved Feb 28, 2008 from $\mathrm{http} / / / \mathrm{www} . c a n a d a . c o m / v a n c o u v e r s u n /$ news/story.html? id=af02aa83-75fc-43e2-9aef-b4265ae8c55e\&k=20 683

\section{Note}

Note 1. There are no definitive statistics on the exact number of tourists as the number is based on observations at the Pacific Rim Visitor Centre booth at the junction of Ucluelet and Tofino. 